\title{
Loss of VHL in RCC reduces repair and alters cellular response to benzo[a]pyrene
}

\author{
Marten A. Schults ${ }^{1}$, Yvonne Oligschlaeger ${ }^{1}$, Roger W. Godschalk ${ }^{1}$, Frederik-Jan Van Schooten ${ }^{1}$ and \\ Roland K. Chiu ${ }^{1,2} *$
}

Department of Toxicology, Maastricht University Medical Centre, NUTRIM-School for Nutrition, Toxicology and Metabolism, Maastricht University, Maastricht, Netherlands

${ }^{2}$ Department of Radiation Oncology, University Medical Center Groningen, University of Groningen, Groningen, Netherlands

\section{Edited by:}

Roel Vermeulen, Utrecht University, Netherlands

\section{Reviewed by:}

Sue Kyung Park, Seoul National University College of Medicine, South Korea

Wagner Ricardo Montor, Faculdade de Ciências Médicas da Santa Casa de São Paulo, Brazil

\section{*Correspondence:}

Roland K. Chiu, Department of Radiation Oncology, University Medical Center Groningen, University of Groningen, P.O. Box 30001,

Groningen 9700 RB, Netherlands e-mail: r.k.chiu@umcg.nl
Mutations of the von Hippel-Lindau (VHL) tumor suppressor gene occur in the majority of sporadic renal-cell carcinomas (RCC). Loss of $V H L$ function is associated with stabilization of hypoxia-inducible factor $\alpha(\mathrm{HIF} \alpha)$. We and others demonstrated that there is a two-way interaction between the aryl hydrocarbon receptor, which is an important mediator in the metabolic activation and detoxification of carcinogens, and the HIF1-pathway leading to an increased genetic instability when both pathways are simultaneously activated. The aim of this study was to investigate how environmental carcinogens, such as benzo[a]pyrene (BaP), which can be metabolically activated to BaP-7,8-diOH-9,10-epoxide (BPDE) play a role in the etiology of RCC. We exposed VHL-deficient RCC4 cells, in which HIF $\alpha$ is stabilized regardless of oxygen tension, to $0.1 \mu \mathrm{M}$ BaP for $18 \mathrm{~h}$. The mutagenic BPDE-DNA adduct levels were increased in HIF $\alpha$ stabilized cells. Using GRT-PCR, we demonstrated that absence of $V H L$ significantly induced the mRNA levels of AhR downstream target CYP1A1. Furthermore, HPLC analysis indicated that loss of VHL increased the concentration of BaP-7,8-dihydroxydiol, the pre-cursor metabolite of BPDE. Interestingly, the capacity to repair BPDE-DNA adducts in the HIF $\alpha$ stabilized RCC4 cells, was markedly reduced. Taken together, these data indicate that loss of $\mathrm{VHL}$ affects BaP-mediated genotoxic responses in RCC and decreases repair capacity.

Keywords: nucleotide excision repair, metabolism, carcinogens, renal-cell carcinoma, von Hippel-Lindau

\section{INTRODUCTION}

Renal-cell carcinoma (RCC) is the most common type of kidney cancer in adults and accounts for $4 \%$ of all cancers (1). The most frequently observed genetic alteration in RCC is the somatic mutation of the von Hippel-Lindau (VHL) tumor suppressor gene $(2,3)$.

The VHL protein (pVHL) is a crucial regulator of the oxygen sensing pathway, which involves the transcription factor hypoxiainducible factor alpha $(\mathrm{HIF} \alpha)(2,4)$. In the presence of oxygen, HIF $\alpha$ is hydroxylated by an oxygen-dependent prolyl hydroxylase (HIF-PH) (5). An E3 ubiquitin ligase complex containing the pVHL recognizes the hydroxylated $\mathrm{HIF} \alpha$, and targets it for ubiquitination (6) and subsequently proteasomal degradation (7). Under hypoxic conditions, HIF $\alpha$ is not prolyl-hydroxylated and thus unrecognized by pVHL.

The stabilized HIF $\alpha$ can translocate to the nucleus where it forms a heterodimer with HIF $1 \beta$, also referred to as aryl hydrocarbon receptor nuclear translocator (ARNT) (8). HIF1 then binds to the promoter/enhancer regions in the DNA (9), where it drives the expression of a wide array of hypoxia-inducible genes to augment oxygen delivery or to provide alternative pathways for energy production and cell metabolism.

The functional loss of pVHL in some RCC results in an aberrant stabilization of HIF $\alpha$ independent of the oxygen tension. The subsequent overexpression of proteins encoded by HIF $\alpha$ regulated target genes contributes to the creation of a microenvironment favorable for cell proliferation $(2,10-12)$.

In many tumors including RCC, the hypoxia-responsive transcription factor HIF $\alpha$ is overexpressed (13), and patients diagnosed with such hypoxic tumors will often have a poor clinical prognosis due to the formation of metastases and the resistance to chemotherapeutics (14). This negative prognosis may occur due to low oxygen concentrations having the capacity to induce genetic instability, leading to increased rates of mutagenesis and angiogenesis, decreased rates of apoptosis and upregulation of genes involved in the metastatic cascade (15). Suppression of the DNA damage response pathways within the hypoxic tumors may also play a critical role (9).

In addition to forming a complex with HIF $\alpha$, HIF1 $\beta$ /ARNT also dimerizes with the aryl hydrocarbon receptor (AhR) which is known to interact with environmental pollutants such as dioxins and polycyclic aromatic hydrocarbons (PAH). PAHs are widely distributed contaminants produced as byproducts of combustion processes such as in vehicle exhaust, cigarette smoking, and charcoal grilling of food. Benzo[a]pyrene $(\mathrm{BaP})$ is a classic example of $\mathrm{PAH}$ and is readily absorbed by inhalation, ingestion, and through the skin. As BaP is lipophilic, it can easily diffuse into cells where it binds to AhR, translocates into the nucleus and subsequently heterodimerizes with HIF1B/ARNT. This complex can then bind to the xenobiotic response elements of target genes (16) where it 
acts as a transcription factor for a number of genes, which encode for enzymes involved in xenobiotic detoxification, including the cytochrome P450 (CYPs) isoforms CYP1A1 and CYP1B1 $(17,18)$.

The detoxification process of $\mathrm{BaP}$ begins with an epoxidation reaction by the mono-oxygenases CYP1A1 and CYP1B1 (phase I). The resulting metabolites (e.g., BaP-7,8-epoxide and BaP-9,10-epoxide) can be converted non-enzymatically to phenols (e.g., 3-OH BaP) or enzymatically to dihydrodiols (e.g., BaP-7,8-diOH or BaP-9,10-diOH) by epoxide hydrolase. Phenols can subsequently be converted to water-soluble sulfate or glucuronide conjugates (phase II) and dihydrodiols can be further transformed by CYP1A1 or CYP1B1 to diol epoxides [e.g., BaP7,8-diol-9,10-epoxide (BPDE)] or conjugated by uridine diphosphate glucuronosyl transferase (UGT) (18). An unfortunate consequence of the detoxification reaction is the production of the intermediate BPDE, which can covalently bind to DNA forming highly mutagenic DNA adducts (17). When unrepaired, these lesions may result in mutations (19).

Previously, we demonstrated that exposure of cells to hypoxia markedly enhances the genetic instability caused by exogenous genotoxins and that HIF activation decreases nucleotide excision repair (NER) (20). Furthermore, we demonstrated that the kinetics of $\mathrm{BaP}$ metabolism is altered under hypoxia resulting in a prolonged time of exposure and a higher amount of BPDE-DNA adducts being formed (Schults et al. manuscript submitted for publication). From these initial studies in which we induced HIF $\alpha$ expression using chemicals or hypoxia, we observed an important link between the HIF1 mediated response pathway and the cellular response pathway that counteracts chemical carcinogens.

In the present study, we hypothesize that in naturally occurring RCC cells that have a defect in HIF regulation, the observed genetic instability may be the result of a faulty response to environmental carcinogens such as BaP. In this current report, we show that loss of VHL affects BaP-mediated genotoxic responses by inducing CYP1A1 mRNA levels, which mediated a significant change in BaP-7,8-diOH, the pre-cursor metabolite of BPDE. Secondly, the capacity to repair DNA by NER is reduced in these cells, thereby preventing the repair of those BPDE-DNA adducts.

\section{MATERIALS AND METHODS \\ CELL CULTURE AND TREATMENT}

RCC4 $\left(V H L^{-1-}\right)$ cells, a VHL-deficient cell line and RCC4-VHL $\left(V_{H} L^{+/+}\right)$, RCC4 reconstituted with $V H L$, were cultured in Dulbecco's Modified Eagle Medium (DMEM; Sigma-Aldrich, UK) supplemented with 10\% heat-inactivated Fecal Calf Serum (FCS; Invitrogen Breda, The Netherlands) and $1 \%$ penicillin streptomycin (P/S; Gibco, Invitrogen, Paisley, $\mathrm{UK})$ at $37^{\circ} \mathrm{C}$ in a $5 \% \mathrm{CO}_{2}$ and $20 \% \mathrm{O}_{2}$ atmosphere. Cells were seeded 1 day before treatment and maintained at $37^{\circ} \mathrm{C}$ in a $5 \% \mathrm{CO}_{2}$ atmosphere. All cells were treated with 0 or $0.1 \mu \mathrm{M} \mathrm{BaP}$ (Sigma) dissolved in DMSO (final concentrations did not exceed $0.5 \%$ ) for $18 \mathrm{~h}$. After treatment medium was removed and cells were harvested using trypsin. All samples were stored at $-20^{\circ} \mathrm{C}$.

\section{QUANTITATIVE REAL-TIME PCR}

Cells were washed twice with PBS and lysed with Trizol (Invitrogen). Total RNA was isolated according to the manufacturer's instructions. The quantity of each RNA sample was spectrophotometrically assessed by a Nanodrop 1000 (Thermo Scientific, Waltham, MA, USA). cDNA synthesis was performed using the iScript cDNA Synthesis kit (Biorad, Veenendaal, The Netherlands) starting with $1 \mu \mathrm{g}$ of RNA. cDNA was diluted $25 \times$ in RNase free water. Real-time PCR was performed using the MyiQ Single Color RT-PCR detection system (Biorad) using Sensimix Sybr Green (Quantace, London, UK), $5 \mu$ l diluted cDNA and $0.3 \mu \mathrm{M}$ (Table 1) primers in a total volume of $25 \mu \mathrm{l}$. Samples were amplified under the following conditions: $95^{\circ} \mathrm{C}$ for $3 \mathrm{~min}$, followed by 40 cycles of $95^{\circ} \mathrm{C}$ for $15 \mathrm{~s}$ and $60^{\circ} \mathrm{C}$ for $45 \mathrm{~s}$. PCR was checked for a-specific products by performing a melting curve analysis $\left(65-95^{\circ} \mathrm{C}\right)$. Data were analyzed using the MyiQ Software system (Biorad) and were expressed as relative gene expression (fold increase) using the $2^{-\Delta \Delta \mathrm{Ct}}$ method. The stably expressed gene cyclophilin A was included as reference.

\section{DNA ISOLATION}

Cells were harvested and resuspended in $400 \mu \mathrm{l}$ SET/SDS (100 mM $\mathrm{NaCl}, 20 \mathrm{mM}$ EDTA, $50 \mathrm{mM}$ Tris, $0.5 \%$ SDS) and incubated at $37^{\circ} \mathrm{C}$ for $2 \mathrm{~h}$. About $50 \mu \mathrm{l}$ of DNAse-free RNAse-solution [RNAse A $(0.1 \mathrm{mg} / \mathrm{ml})$ and RNAse T1 $(1000 \mathrm{U} / \mathrm{ml})$ in SET, incubated at $80^{\circ} \mathrm{C}$ for $5 \mathrm{~min}$ ] was added and samples were incubated at $37^{\circ} \mathrm{C}$ for $1 \mathrm{~h}$ followed by adding $50 \mu \mathrm{l}$ DNAse-free proteinase $\mathrm{K}(10 \mathrm{mg} / \mathrm{ml}$ in SET-SDS, heat-inactivated at $37^{\circ} \mathrm{C}$ for $30 \mathrm{~min}$ ) and samples were incubated overnight at $37^{\circ} \mathrm{C}$. After addition of $500 \mu l$ phenol/chloroform/Isoamylalcohol (25:24:1), samples were rotated

Table 1 | Primer sequences for real-time RT-PCR

\begin{tabular}{|c|c|c|c|}
\hline Gene & & Sequence $5^{\prime} \rightarrow \mathbf{3}^{\prime}$ & $\begin{array}{l}\text { Accession } \\
\text { number }\end{array}$ \\
\hline $\begin{array}{l}\text { Cyclo- } \\
\text { philin a }\end{array}$ & $\begin{array}{l}\text { Forward } \\
\text { Reverse }\end{array}$ & $\begin{array}{l}\text { TTCCTGCTTTCACAGAATTATTCC } \\
\text { GCCACCAGTGCCATTATGG }\end{array}$ & NM_021130.3 \\
\hline CYP1A1 & $\begin{array}{l}\text { Forward } \\
\text { Reverse }\end{array}$ & $\begin{array}{l}\text { TCCTGGAGACCTTCCGACACT } \\
\text { CTTTCAAACTTGTGTCTCTTGTTGTG }\end{array}$ & NM_000499.3 \\
\hline CYP1B1 & $\begin{array}{l}\text { Forward } \\
\text { Reverse }\end{array}$ & $\begin{array}{l}\text { AGTGCAGGCAGAATTGGATCA } \\
\text { GCGCATGGCTTCATAAAGGA }\end{array}$ & NM_000104.3 \\
\hline XPA & $\begin{array}{l}\text { Forward } \\
\text { Reverse }\end{array}$ & $\begin{array}{l}\text { CCGACAGGAAAACCGAGAAA } \\
\text { TTCCACACGCTGCTTCTTACTG }\end{array}$ & NM_000380.3 \\
\hline XPC & $\begin{array}{l}\text { Forward } \\
\text { Reverse }\end{array}$ & $\begin{array}{l}\text { CCCAGCCCGCTTTACCA } \\
\text { TGCATTAACTGTAAATGTTCCAATGA }\end{array}$ & NM_004628.4 \\
\hline ERCC4 & $\begin{array}{l}\text { Forward } \\
\text { Reverse }\end{array}$ & $\begin{array}{l}\text { CACCTCCCTCGCCGTGTA } \\
\text { CGCAAATATAACACCACCTTGTG }\end{array}$ & NM_005236.2 \\
\hline ERCC5 & $\begin{array}{l}\text { Forward } \\
\text { Reverse }\end{array}$ & $\begin{array}{l}\text { GCATGAAATCTTGACTGATATGAAAGA } \\
\text { TAAGCAAGCCTTTGAGTTGGTACTG }\end{array}$ & NM_000123.3 \\
\hline ERCC1 & $\begin{array}{l}\text { Forward } \\
\text { Reverse }\end{array}$ & $\begin{array}{l}\text { ACCCCTCGACGAGGATGAG } \\
\text { CAGTGGGAAGGCTCTGTGTAGA }\end{array}$ & NM_202001.2 \\
\hline GSTP1 & $\begin{array}{l}\text { Forward } \\
\text { Reverse }\end{array}$ & $\begin{array}{l}\text { CTCAAAAGGCTTCAGTTGCC } \\
\text { ACCTCCGCTGCAAATACATC }\end{array}$ & NM_000852.3 \\
\hline EPHX1 & $\begin{array}{l}\text { Forward } \\
\text { Reverse }\end{array}$ & $\begin{array}{l}\text { CTTCACGTGGATGAAGTGGA } \\
\text { CTGGCGGAATGAATTTGACT }\end{array}$ & NM_000120.3 \\
\hline UGT1A6 & $\begin{array}{l}\text { Forward } \\
\text { Reverse }\end{array}$ & $\begin{array}{l}\text { GGAACCCGACCATCGAATC } \\
\text { TCGGGTGACCAAGCAGATC }\end{array}$ & NM_001072.3 \\
\hline UGT2B7 & $\begin{array}{l}\text { Forward } \\
\text { Reverse }\end{array}$ & $\begin{array}{l}\text { TCCCATCAAATCTCCACAGA } \\
\text { GGTGTTTTCTCTGGGGTCAA }\end{array}$ & NM_001074.2 \\
\hline
\end{tabular}


for $5 \mathrm{~min}$ and centrifuged for $5 \mathrm{~min}$ at $14000 \mathrm{rpm}$. To the upperphase, $500 \mu \mathrm{l}$ chloroform/Isoamylalcohol (24:1) was added and samples were $5 \mathrm{~min}$ rotated, centrifuged for $5 \mathrm{~min}(14000 \mathrm{rpm})$ and $1 / 30$ volume $\mathrm{NaAc}$ ( $3 \mathrm{M}, \mathrm{pH} 5.2$ ) was added to the upperphase. Samples were mixed for a few seconds and two volumes ethanol $100 \%\left(4^{\circ} \mathrm{C}\right)$ were added, samples were mixed and incubated at $-20^{\circ} \mathrm{C}$ for $30 \mathrm{~min}$. Samples were centrifuged for $5 \mathrm{~min}$ and DNA pellets were washed with ethanol 70\%. DNA pellets were dried and resuspended in Mili-Q $\mathrm{H}_{2} \mathrm{O}$. The quantity and quality of DNA was measured using the Nanodrop 1000.

\section{${ }^{32}$ P-POSTLABELING OF BPDE-DNA ADDUCTS}

DNA adduct levels were determined according to the nuclease P1 enrichment technique originally described by Reddy and Randerath (21) with the modifications described by Godschalk et al. (22). In all experiments, three BPDE-DNA standards with known BPDE-DNA adduct levels (one adduct per $10^{6}, 10^{7}$, and $10^{8}$ normal nucleotides) were analyzed in parallel for quantification purposes. Adducts spots in DNA from BaP treated RCC4 cells that chromatographed at the same position as the BPDE-DNA adducts standards were considered to be derived from BPDE, and were quantified using Phosphor-Imaging technology (Fujifilm FLA-3000, Rotterdam, The Netherlands).

\section{HPLC}

In order to determine BaP-metabolite composition, $4 \mathrm{ml}$ medium was extracted with $1 \mathrm{ml}$ ethyl acetate after addition of $1 \mathrm{ml} 3 \mathrm{M}$ $\mathrm{NaCl}$. Samples were vortexed for $10 \mathrm{~min}$, centrifuged for $5 \mathrm{~min}$ at $1000 \mathrm{rpm}$ and after briefly vortexed, centrifuged again for $10 \mathrm{~min}$ at $1500 \mathrm{rpm}$. The ethyl acetate fraction was collected and the extraction step was repeated twice. The second time and third time, only ethyl acetate was added and the third time, also two droplets of ethanol were added to the samples for better separation. The ethyl acetate fractions were combined, evaporated to dryness under $\mathrm{N}_{2}$, and residues were resuspended in $0.5 \mathrm{ml}$ methanol. For chromatographic separation, a $50 \mu \mathrm{l}$ volume of the sample was injected onto a Hypersil $5 \mu \mathrm{m}$ ODS HPLC column (250 $\mathrm{mm} \times 3 \mathrm{~mm}$ i.d.) (Supelco 54933, Bellefonte, PA, USA) at a flow rate of $0.5 \mathrm{ml} / \mathrm{min}$. Mobile phase A and B were $100 \%$ methanol (Biosolve Chemicals, Valkenswaard, The Netherlands) and $40 \%$ methanol in water, respectively. The time program for the multi-step gradient was: $0-5 \mathrm{~min}$ : isocratically $40 / 60(\mathrm{~A} / \mathrm{B}$, $\mathrm{v} / \mathrm{v}), 5-30 \mathrm{~min}$ : gradient from $40 / 60(\mathrm{~A} / \mathrm{B}, \mathrm{v} / \mathrm{v})$ to $90 / 10(\mathrm{~A} / \mathrm{B}$, v/v), 30-35 min: isocratically 90/10 (A/B, v/v), 35-37 min: gradient from $90 / 10(\mathrm{~A} / \mathrm{B}, \mathrm{v} / \mathrm{v})$ to $40 / 60(\mathrm{~A} / \mathrm{B}, \mathrm{v} / \mathrm{v}), 37-40 \mathrm{~min}$ : $40 / 60(\mathrm{~A} / \mathrm{B}, \mathrm{v} / \mathrm{v})$. The total run time was $40 \mathrm{~min}$. For quantitation purposes, a standard mix consisting of $50 \mathrm{ng} / \mathrm{ml} \mathrm{BaP-9,10-}$ diOH, 50 ng/ml BaP-7,8-diOH, and 50 ng/ml 3-OH BaP (Midwest Research Institute, Kansas City, MO, USA) was used. Samples were analyzed on a Gynkotek P580A HPLC system (Separations Analytical Instruments, Hendrik Ido Ambacht, The Netherlands) with a Spark SP830 autosampler (Spark Holland, Emmen, The Netherlands) and a Perkin Elmer LS-30 programmable fluorescence detector (Perkin Elmer, Foster City, CA, USA). Excitation/emission wavelengths were $257 />350 \mathrm{~nm}$. For quantification, the area of each metabolite peak on the chromatogram was determined.

\section{MEASUREMENT OF REPAIR CAPACITY}

To assess NER capacity in the liver samples, we applied a well characterized and validated modified comet assay (23). This assay measures the ability of NER-related enzymes that are present in cell extracts, to incise substrate DNA containing BPDE-DNA adducts. The substrate nucleoids were prepared from untreated A549 cells (human epithelial lung carcinoma cells) obtained from the American Tissue Culture Collection (ATCC, Rockville, MD, USA). The cells were cultured in DMEM supplemented with $10 \%$ heat-inactivated FCS and 1\% penicillin/streptomycin and maintained at $37^{\circ} \mathrm{C}$ in a $5 \% \mathrm{CO}_{2}$ atmosphere. A549 cells were embedded in LMP agarose on glass microscope slides and subsequently lyses overnight in cold $\left(4^{\circ} \mathrm{C}\right)$ lysis buffer $(2.5 \mathrm{M} \mathrm{NaCl}$, $0.1 \mathrm{M}$ EDTA, $0.01 \mathrm{M}$ Tris, $0.25 \mathrm{M} \mathrm{NaOH}$ plus $1 \%$ Triton $\mathrm{X}-100$ and $10 \%$ DMSO). The resulting nucleoids were then either exposed to $1 \mu \mathrm{M}$ BPDE (NCI Chemical Carcinogen Reference Standard Repository, Midwest Research Institute, Kansas City, MO, USA) in PBS or vehicle control (DMSO, $0.5 \%$ ) for $30 \mathrm{~min}$ at $4^{\circ} \mathrm{C}$. To prepare protein/enzyme extracts, RCC4 and RCC4-VHL cells were harvested and resuspended in buffer A ( $45 \mathrm{mM}$ HEPES, $0.4 \mathrm{M} \mathrm{KCl}$, $1 \mathrm{mM}$ EDTA, $0.1 \mathrm{mM}$ dithiothreitol, $10 \%$ glycerol, adjusted to $\mathrm{pH}$ 7.8 using $\mathrm{KOH}$ ). Resulting aliquots were snap-frozen, thawed again and $30 \mu \mathrm{l}$ of $1 \%$ Triton X-100 in buffer A per $100 \mu$ l of extract was added. Protein concentrations were determined by the BioRAD DC protein assay using bovine serum albumin as a standard. Tissue extracts were diluted to a concentration of $1 \mathrm{mg} / \mathrm{ml}$. Next, four volumes of reaction buffer B (45 mM HEPES, $0.25 \mathrm{mM}$ EDTA, 2\% glycerol, $0.3 \mathrm{mg} / \mathrm{ml} \mathrm{BSA}$, adjusted to $\mathrm{pH} 7.8$ with $\mathrm{KOH}$ ) were added and $50 \mu \mathrm{l}$ of the mixture was added to the gel-embedded nucleoids and incubated for $20 \mathrm{~min}$ at $37^{\circ} \mathrm{C}$. Alkaline treatment $(40 \mathrm{~min})$ and electrophoresis $(30 \mathrm{~min}$ ) were conducted as described in the standard comet assay (24). Comets were visualized using a Zeiss Axioskop fluorescence microscope and quantified as tail moment. Samples were tested in two independent incubations within each single experiment. On every slide, 50 cells were analyzed randomly using the Comet assay III software program (Perspective Instruments, Haverhill, UK). The increased DNA strand breakage (tail moment) in the BPDE-modified nucleoids vs. the DMSO-treated nucleoids is indicative for the NER capacity of the cell extracts. The final repair capacity was calculated according to Langie et al. (23).

\section{STATISTICAL ANALYSIS}

Results are expressed as the mean \pm SE of the mean. GraphPad Prism 4 was used for statistical analysis. A two-way analysis of variance (ANOVA) with Bonferroni post hoc multiple comparison correction was used to assess differences in mRNA levels. To analyze differences in, metabolite levels, adduct levels, and repair capacity a Student's $t$-test was used. Differences were considered to be statistically significant when $P<0.05$.

\section{RESULTS}

\section{BPDE-DNA ADDUCT LEVELS ARE HIGHER IN CELLS DEFICIENT IN VHL}

To examine the influence of $V H L$ deletion on BaP-mediated genotoxic responses, we quantified the amount of BPDE-DNA adducts in VHL-deficient RCC4 cells and compared it with the genetically wild type RCC4-VHL cells and normalized it to the total amount of DNA (Figure 1). Exposure to $0.1 \mu \mathrm{M} \mathrm{BaP}$ resulted in 


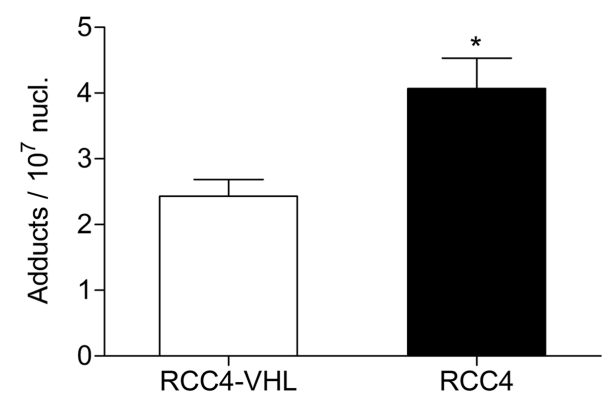

FIGURE 1 | BPDE-DNA adduct levels are higher in cell deficient in $\mathbf{V H L}$. RCC4-VHL and RCC4 cells were incubated with $0.1 \mu \mathrm{M} \mathrm{BaP}$. DNA was isolated after $18 \mathrm{~h}$ and BPDE-DNA adduct levels were measured by ${ }^{32}$ P-postlabeling. Data $(n=4)$ are presented as mean adduct level per $10^{7}$ nucleotides \pm SE (* $P<0.05$, Student's $t$-test).

$\mathrm{a} \sim 1.7$-fold greater formation of the pro-mutagenic BPDE-DNA adduct in RCC4 cells, compared to RCC4-VHL cells $(P<0.05)$.

\section{CELLS DEFICIENT IN VHL HAVE CHANGES GENE EXPRESSION OF METABOLIC ENZYMES}

Since metabolism may be the underlying cause of the increase in BPDE-DNA adducts in cells deficient in VHL, we assessed the mRNA expression of several key phase I and II metabolic enzymes. Of the phase I enzymes responsible for the activation of BaP, CYP1A1 mRNA levels significantly differ between the two cell lines (Figure 2A). The CYP1A1 mRNA levels were $\sim 31$ and $\sim 5.8$ times higher in the RCC4 cells compared to the RCC4-VHL cells $(P<0.01)$, for untreated and BaP treated cells, respectively. CYP1B1 gene expression was not statistically different between the two cell lines (Figure 2B). Gene expression of four phase II enzymes responsible for the conjugation of $\mathrm{BaP}$ metabolites was also measured. The expression of the glutathione S-transferases GSTP1 was $\sim 24 \%$ lower in RCC4 cells compared to RCC4-VHL cells $(P<0.05$, Figure 3A). Epoxide hydrolase 1 (Figure 3B) and the UDP glucuronosyltransferases UGT1A6 (Figure 3C) showed no difference between the two cell lines. Conversely, UGT2B7 expression was $\sim 1.5$ and 1.6 times higher (DMSO and BaP treatment respectively) in RCC4 cells compared to the RCC4-VHL cells (Figure 3D).

\section{ABSENCE OF VHL DIRECTS BaP METABOLISM TOWARD UNFAVORABLE ACTIVATION}

To determine whether the observed differences in BaP metabolic enzymes between the two cell lines resulted in the expected detrimental changes in $\mathrm{BaP}$ metabolism, we assessed $\mathrm{BaP}$ and its metabolites BaP-9,10-diOH, BaP-7.8-diOH and 3-OH BaP by HPLC analysis with fluorescence detection. RCC4 and RCC4-VHL were exposed for $18 \mathrm{~h}$ to $0.1 \mu \mathrm{M} \mathrm{BaP}$ and the medium was collected. The rate of metabolism was determined from measuring the remaining amount of unmetabolized BaP. In the medium, a non-statistically significant twofold higher level of $\mathrm{BaP}$ was measured in the RCC4 cells compared to the control RCC4-VHL cells (Figure 4A). For all three metabolites assessed, statistically significant higher levels of metabolites were found in the medium of the RCC4 cells compared to the RCC4-VHL cells. A $\sim 1.7$ - and
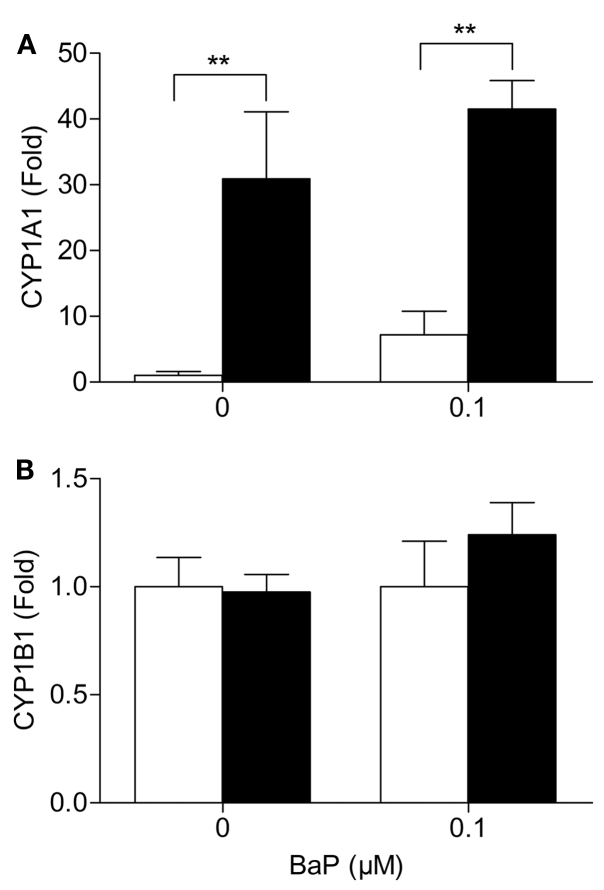

FIGURE 2 | CYP1A1 but not CYP1B1 mRNA expression, is markedly enhanced in $\mathbf{V H}$ defective cells. RCC4-VHL ( $\square$ ) and RCC4 cells ( $\square$ ) were incubated with DMSO or $0.1 \mu \mathrm{M} \mathrm{BaP}$ for $18 \mathrm{~h}$. RNA was isolated and mRNA levels were measured of (A) CYP1A1 and (B) CYP1B1. Data $(n=4)$ are presented as mean fold change \pm SE $\left({ }^{*} P<0.01\right)$.

2.7-fold induction of $\mathrm{BaP}-9,10-\mathrm{diOH}$ and 3-OH $\mathrm{BaP}$, respectively, was observed in RCC4 cells compared to RCC4-VHL cells (Figures 4B,C). Furthermore, compared to RCC4-VHL cells, BaP7,8-diOH levels, the BPDE pre-cursor, were $\sim 2.9$ times higher in RCC4 cells (Figure 4D).

\section{NUCLEOTIDE EXCISION REPAIR CAPACITY IS REDUCED IN VHL-DEFICIENT CELLS}

As we previously reported a downregulation of NER capacity in HIF $\alpha$ stabilized cells, we sought to determine whether diminished DNA repair may also play a role in the observed differences in BPDE-DNA adduct levels induction between the RCC4 and RCC4-VHL cells. Firstly, we determined the influence of DNA repair gene expression in the matched cells. The mRNA levels of the critical NER genes XPA, XPC, ERCC1, ERCC5, and ERCC4 were not altered in the cell lines (Table 2). Secondly, as DNA repair is often not regulated at the transcription level, we used a validated modified comet assay to determine the functional NER capacity. A markedly reduced repair capacity was observed in the VHL-deficient cells compared to the reconstituted RCC4-VHL cells (Figure 5).

\section{DISCUSSION}

Previously, we demonstrated that the stabilization of HIF $\alpha$ by $\mathrm{CoCl}_{2}$ enhanced the carcinogenic effect of $\mathrm{BaP}$ in lung cancer cells and reduced repair (20). Furthermore, we demonstrated that the kinetics of carcinogen metabolism altered under hypoxic 

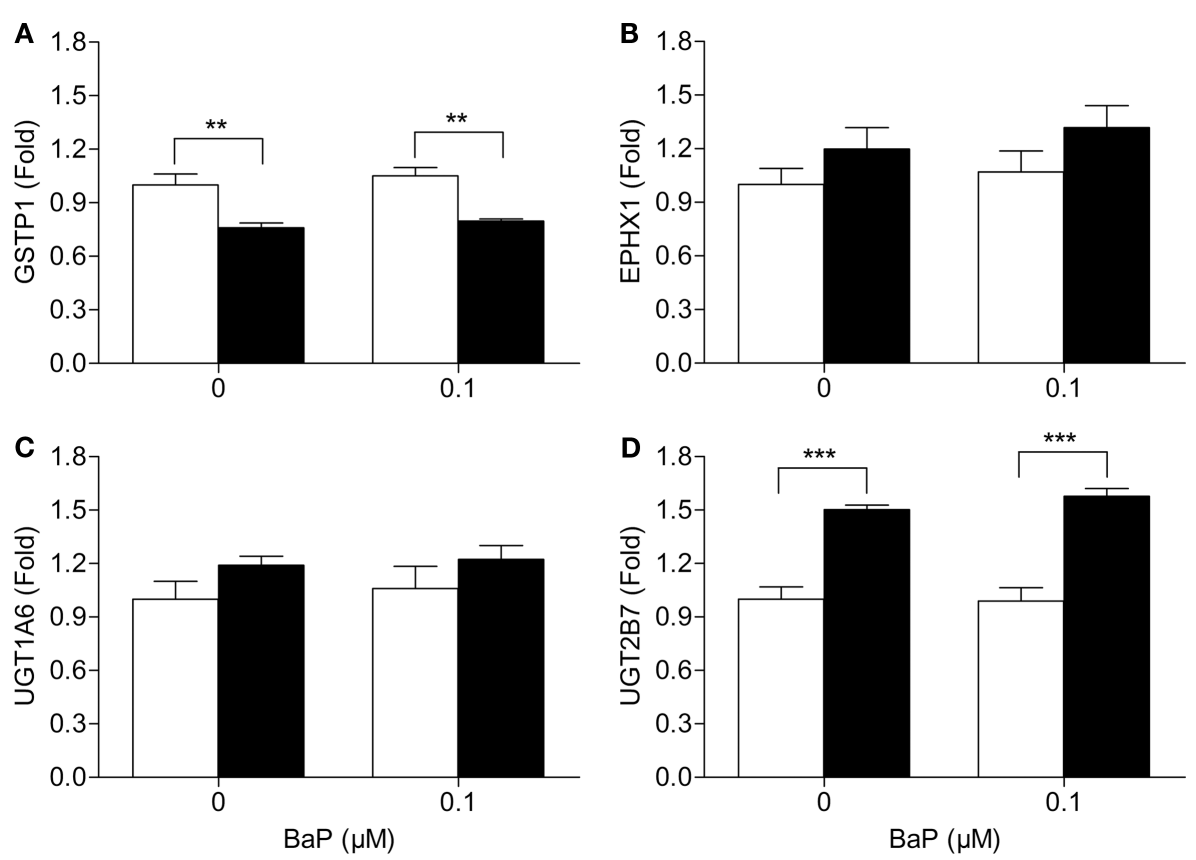

FIGURE 3 | Loss of $\mathbf{V H L}$ increases UGT2B7, but decreases GSTP1 gene expression. RCC4-VHL ( $\square$ ) and RCC4 cells ( $\square$ ) were incubated with DMSO or $0.1 \mu \mathrm{M} \mathrm{BaP}$ for $18 \mathrm{~h}$. RNA was isolated and mRNA levels were measured

of (A) GSTP1, (B) EPHX1, (C) UGT1A6, and (D) UGT2B7. Data $(n=4)$ are presented as mean fold change $\pm \mathrm{SE}\left({ }^{*} P<0.01\right.$, ${ }^{* * *} P<0.001$, two-way ANOVA with Bonferroni post hoc multiple comparison correction).
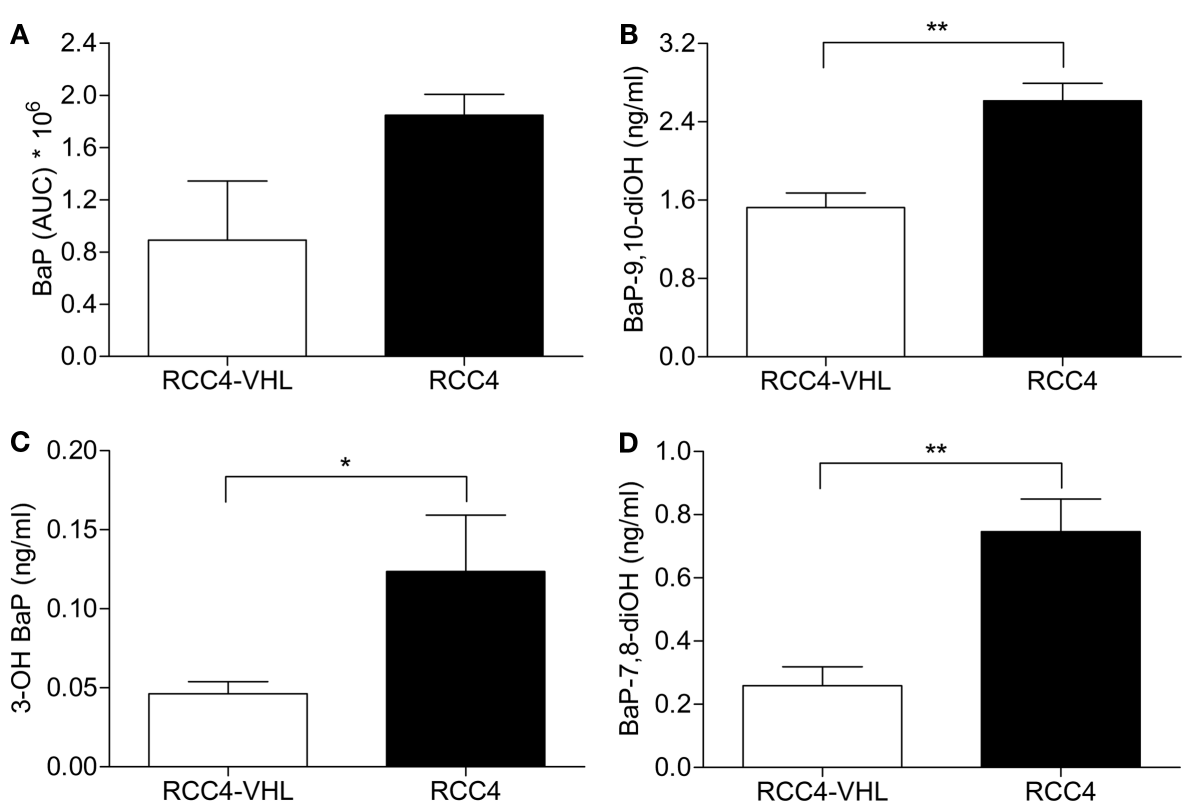

FIGURE 4 | Absence of $\mathbf{V H}$ decreased BaP metabolism, but increased BaP metabolites. RCC4-VHL ( $\square$ ) and RCC4 cells ( $\square$ ) were incubated with $0.1 \mu \mathrm{M} \mathrm{BaP}$ for $18 \mathrm{~h}$ and extracellular unmetabolized BaP (A), BaP-9, 10-diOH

(B), BaP-7,8-diOH (C), and 3-OH BaP (D) metabolites were measured. Data $(n=5)$ are presented as mean area under the curve \pm SE $\left({ }^{*} P<0.05\right.$, ${ }^{*} P<0.01$; Student's $t$-test).

conditions, resulting in more BPDE-DNA adducts being formed (Schults et al. manuscript submitted for publication). The aim of the current study was to determine whether similar genetic instability mechanisms hold true in the naturally occurring
$V H L$-deficient RCC cells. In this report, we demonstrate that the loss of VHL and via presumably the stabilization of HIF $\alpha$, affects both genetic stability related processes of BaP-mediated and DNA repair capacity in RCC cells. 
Table 2 | Relative NER gene expression.

\begin{tabular}{|c|c|c|c|c|c|c|}
\hline BaP & & XPA & XPC & ERCC4 & ERCC5 & ERCC1 \\
\hline \multirow[t]{2}{*}{$0 \mu \mathrm{M}$} & RCC4-VHL & $1.00 \pm 0.02$ & $1.00 \pm 0.14$ & $1.00 \pm 0.08$ & $1.00 \pm 0.10$ & $1.00 \pm 0.09$ \\
\hline & $\mathrm{RCC} 4$ & $0.94 \pm 0.05$ & $0.98 \pm 0.12$ & $0.98 \pm 0.03$ & $1.16 \pm 0.11$ & $1.09 \pm 0.06$ \\
\hline \multirow[t]{2}{*}{$0.1 \mu \mathrm{M}$} & RCC4-VHL & $1.02 \pm 0.04$ & $1.04 \pm 0.16$ & $0.95 \pm 0.08$ & $0.98 \pm 0.08$ & $1.01 \pm 0.02$ \\
\hline & $\mathrm{RCC} 4$ & $1.15 \pm 0.05$ & $1.17 \pm 0.19$ & $0.89 \pm 0.02$ & $1.21 \pm 0.12$ & $1.17 \pm 0.09$ \\
\hline
\end{tabular}

Statistical method used: two-way ANOVA with Bonferroni post hoc multiple comparison correction.

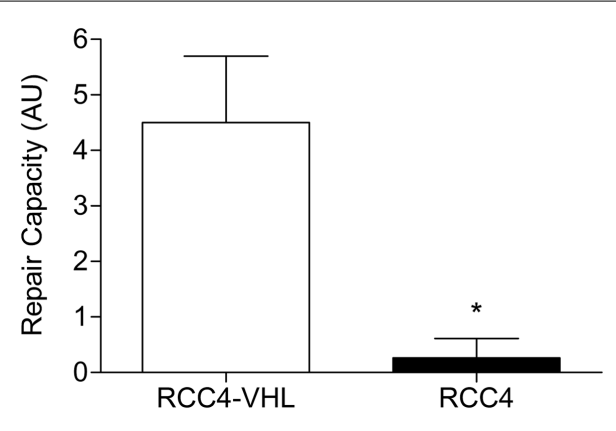

FIGURE 5 | NER capacity is decreased in RCC4 cells. The ability to repair BPDE-DNA adducts in RCC4-VHL and RCC4 cells were measured using the modified comet assay (23). Data $(n=4)$ are presented as mean fold change $\pm \mathrm{SE}\left({ }^{*} P<0.05\right.$, Student's $t$-test).

Cytochrome P450 enzymatically converts BaP into BPDE. This active metabolite subsequently binds DNA covalently forming highly mutagenic DNA adducts (17). To investigate the effect of metabolically activated $\mathrm{BaP}$ on RCC4 cells, the formation of BPDE-DNA adducts was determined. Our data demonstrated that $V H L$ deficiency resulted in increased BPDE-DNA adduct levels in RCC4 cells, compared to RCC4-VHL cells, when treated with $0.1 \mu \mathrm{M} \mathrm{BaP}$. This is in agreement with our previously observed results, where the formation of BPDE-DNA adducts was increased due to stabilization of $\mathrm{HIF} \alpha$ by $\mathrm{CoCl}_{2}$ in A549 cells (20).

To determine whether metabolism may be the cause of the increased BPDE-DNA adduct levels in VHL-deficient cells changes in gene expression of relevant enzymes in the metabolism of $\mathrm{BaP}$ were assessed. CYP1A1 and CYP1B1 are two of the most important enzymes in the detoxification and bioactivation of $\mathrm{BaP}(17,18)$. Furthermore, CYP1A1 is the critical enzyme in the bioactivation of $\mathrm{BaP}-7,8-\mathrm{diOH}$ to the ultimate carcinogenic BPDE metabolites in human lung cell lines in vitro (25). In this study, we demonstrate that CYP1A1 mRNA levels were strongly upregulated in the HIF $\alpha$ stabilized RCC4 cells compared to the reconstituted genetically wild type cells. As CYP1B1 mRNA levels were unaffected by VHL loss, CYP1A1 appears to be the critical player in RCC metabolism of $\mathrm{BaP}$ in these cells. Induction of CYP1A1 in HIF $\alpha$-stabilized cells may result in an increased level of BPDE formation, which may subsequently induce carcinogenicity. This observation compares well with studies in other cell types where CYP1A1 activity has been positively correlated with pulmonary PAH (BPDE)associated DNA adduction (26), and high CYP1A1 inducibility in lymphocytes has been related to a high lung cancer risk $(27,28)$.

The resulting metabolites of $\mathrm{BaP}$ can be converted into hydrophilic products by phase II enzymes (18). Alterations in these conjugation reactions result in changed elimination of these compounds and subsequently BPDE-DNA adducts level. No pattern was observed for phase II enzymes, suggesting that they are not likely involved in the observed different BPDE-DNA adduct levels identified between the two cell lines. Nevertheless, measuring BaP metabolites provides a better insight into differences in $\mathrm{BaP}$ metabolism between the two RCC4 cell lines. BaP-9,10-diOH was the most abundant metabolite present in the media of both cell lines. This metabolite subsequently forms BaP-9,10-diol-7,8-epoxide, which importantly is far less carcinogenic than BPDE. We further observed that the increased levels of metabolites and in particular $\mathrm{BaP}-7,8-\mathrm{diOH}$, which can be oxidized to BPDE, correlates well with the observed increased DNA adducts levels. Together, these data indicate that $V H L$-deficient RCC cells are able to differentially bioactivate $\mathrm{BaP}$ as compared to the reconstituted RCC4-VHL cells suggesting a plausible explanation for the increased DNA adduct formation in RCC4 cells.

The level of DNA adducts is influenced by the balance between the induction of the damage and its repair. Therefore, in addition to the formation of adducts, we further analyzed whether loss of VHL influences NER since the bulk of adducts are removed by this DNA repair pathway (29). Our data indicate that the loss of VHL had no effect on DNA repair gene expression. As DNA repair is often regulated in multiple levels in addition to transcriptional control, we sought to determine whether NER is functionally impaired by HIF $\alpha$ stabilization. To determine the functionality of NER, we used a previously validated modified comet assay, which predominantly assesses the cellular capacity in the recognition and incision phase of NER to remove bulky DNA adducts (23). A dramatically lower repair capacity was observed in the VHL-deficient RCC4 cells. Reduced NER capacity under hypoxic conditions was previously demonstrated in mouse fibroblasts (30) and in HIF $\alpha$ stabilized A549 cells (20). In the present study, we show that lack of $V H L$ in cells also results in a decreased repair capacity. The reduced NER repair further explains the observed higher BPDE-DNA adduct levels in VHL-deficient RCC cells.

In this study, we provide evidence that loss of VHL presumably via the stabilization of HIF affects the BPDE-DNA adduct levels in RCC cells and is in fact a double edged sword. Firstly, the absence of $V H L$ is associated with induced CYP1A1 mRNA levels, which mediated a significant change in BaP-7,8-diOH levels among other metabolites. This could significantly induce the 
formation of BPDE-DNA adduct levels. Secondly, the capacity to repair DNA by NER is reduced in HIF $\alpha$ stabilized cells, thereby preventing the repair of those BPDE-DNA adducts. Taken together, these data indicate that loss of $V H L$ increases carcinogen genotoxicity in RCC in vitro and provides potential insight in the malignant progression into RCC.

\section{REFERENCES}

1. Jemal A, Siegel R, Xu J, Ward E. Cancer statistics, 2010. CA Cancer J Clin (2010) 60:277-300. doi:10. 3322/caac. 20073

2. Cohen HT, McGovern FJ. Renalcell carcinoma. $N$ Engl J Med (2005) 353:2477-90. doi:10.1056/ NEJMra043172

3. Baldewijns MM, Van Vlodrop IJ, Vermeulen PB, Soetekouw PM, Van Engeland M, De Bruine AP. VHL and HIF signalling in renal cell carcinogenesis. J Pathol (2010) 221:125-38. doi:10.1002/path.2689

4. Nyhan MJ, O'Sullivan GC, Mckenna SL. Role of the VHL (von HippelLindau) gene in renal cancer: a multifunctional tumour suppressor. Biochem Soc Trans (2008) 36:472-8. doi:10.1042/BST0360472

5. Jaakkola P, Mole DR, Tian YM, Wilson MI, Gielbert J, Gaskell SJ, et al. Targeting of HIF-alpha to the von Hippel-Lindau ubiquitylation complex by O2-regulated prolyl hydroxylation. Science (2001) 292:468-72. doi:10.1126/science. 1059796

6. Cockman ME, Masson N, Mole DR, Jaakkola P, Chang GW, Clifford SC, et al. Hypoxia inducible factor-alpha binding and ubiquitylation by the von Hippel-Lindau tumor suppressor protein. J Biol Chem (2000) 275:25733-41. doi:10. 1074/jbc.M002740200

7. Kallio PJ, Wilson WJ, O’Brien S, Makino Y, Poellinger L. Regulation of the hypoxia-inducible transcription factor lalpha by the ubiquitinproteasome pathway. J Biol Chem (1999) 274:6519-25. doi:10.1074/ jbc.274.10.6519

8. Wang GL, Jiang BH, Rue EA, Semenza GL. Hypoxia-inducible factor 1 is a basic-helix-loop-helixPAS heterodimer regulated by cellular O2 tension. Proc Natl Acad Sci U $S$ A (1995) 92:5510-4. doi:10.1073/ pnas.92.12.5510

9. Semenza GL, Jiang BH, Leung SW, Passantino R, Concordet JP, Maire $\mathrm{P}$, et al. Hypoxia response elements in the aldolase A, enolase 1, and lactate dehydrogenase A gene promoters contain essential binding sites for hypoxia-inducible factor 1 . J Biol Chem (1996) 271:32529-37. doi:10. 1074/jbc.271.51.32529

10. Kondo K, Kim WY, Lechpammer M, Kaelin WG Jr. Inhibition of HIF2alpha is sufficient to suppress pVHL-defective tumor growth. PLoS Biol (2003) 1:E83. doi: 10.1371/journal.pbio.0000083

11. Raval RR, Lau KW, Tran MG, Sowter HM, Mandriota SJ, Li JL, et al. Contrasting properties of hypoxia-inducible factor 1 (HIF-1) and HIF-2 in von Hippel-Lindauassociated renal cell carcinoma. $\mathrm{Mol}$ Cell Biol (2005) 25:5675-86. doi:10. 1128/MCB.25.13.5675-5686.2005

12. Wright TM, Rathmell WK. Identification of Ror2 as a hypoxia-inducible factor target in von Hippel-Lindau-associated renal cell carcinoma. $J$ Biol Chem (2010) 285:12916-24. doi:10.1074/jbc.M109.073924

13. Zhong H, De Marzo AM, Laughner E, Lim M, Hilton DA, Zagzag $\mathrm{D}$, et al. Overexpression of hypoxiainducible factor lalpha in common human cancers and their metastases. Cancer Res (1999) 59:5830-5.

14. Maxwell PH, Wiesener MS, Chang GW, Clifford SC, Vaux EC, Cockman ME, et al. The tumour suppressor protein VHL targets hypoxia-inducible factors for oxygen-dependent proteolysis. Nature (1999) 399:271-5. doi:10.1038/20459

15. Kallio PJ, Pongratz I, Gradin K, Mcguire J, Poellinger L. Activation of hypoxia-inducible factor lalpha: posttranscriptional regulation and conformational change by recruitment of the Arnt transcription factor. Proc Natl Acad Sci U S A (1997) 94:5667-72. doi:10.1073/ pnas.94.11.5667

16. Reyes H, Reisz-Porszasz S, Hankinson O. Identification of the Ah receptor nuclear translocator protein (Arnt) as a component of the DNA binding form of the Ah receptor. Science (1992) 256:1193-5. doi: 10.1126/science.256.5060.1193

17. Gelboin HV. Benzo[alpha]pyrene metabolism, activation and carcinogenesis: role and regulation of mixed-function oxidases and related enzymes. Physiol Rev (1980) 60:1107-66.

18. Baird WM, Hooven LA, Mahadevan B. Carcinogenic polycyclic aromatic hydrocarbon-DNA adducts and mechanism of action. Environ Mol Mutagen (2005) 45:106-14. doi: 10.1002/em.20095

\section{ACKNOWLEDGMENTS}

The authors thank the Province of Limburg, the Netherlands for financial support. Part of the studies was supported by the European Network of Excellence (NoE) "Environmental cancer, nutrition and individual susceptibility" (ECNIS), sixth Framework program (FP6), FOOD-CT-2005-513943.

19. Pfeifer GP, Denissenko MF, Olivier M, Tretyakova N, Hecht SS, Hainaut P. Tobacco smoke carcinogens, DNA damage and p53 mutations in smoking-associated cancers. Oncogene (2002) 21:7435-51. doi:10. 1038/sj.onc. 1205803

20. Schults MA, Timmermans L, Godschalk RW, Theys J, Wouters BG, Van Schooten FJ, et al. Diminished carcinogen detoxification is a novel mechanism for hypoxia-inducible factor 1mediated genetic instability. J Bio Chem (2010) 285:14558-64. doi:10. 1074/jbc.M109.076323

21. Reddy MV, Randerath K. Nuclease P1-mediated enhancement of sensitivity of 32P-postlabeling test for structurally diverse DNA adducts. Carcinogenesis (1986) 7:1543-51. doi:10.1093/carcin/7.9.1543

22. Godschalk RW, Maas LM, Van Zandwijk N, Van 't Veer LJ, Breedijk A, Borm PJ, et al. Differences in aromatic-DNA adduct levels between alveolar macrophages and subpopulations of white blood cells from smokers. Carcinogenesis (1998) 19:819-25. doi:10.1093/ carcin/19.5.819

23. Langie SA, Knaapen AM, Brauers KJ, Van Berlo D, Van Schooten FJ, Godschalk RW. Development and validation of a modified comet assay to phenotypically assess nucleotide excision repair. Mutagenesis (2006) 21:153-8. doi:10.1093/ mutage/gel013

24. Knaapen AM, Schins RP, Borm PJ, Van Schooten FJ. Nitrite enhances neutrophil-induced DNA strand breakage in pulmonary epithelial cells by inhibition of myeloperoxidase. Carcinogenesis (2005) 26:1642-8. doi:10.1093/carcin/bgil16

25. Uppstad H, Ovrebo S, Haugen A, Mollerup S. Importance of CYP1A1 and CYP1B1 in bioactivation of benzo[a]pyrene in human lung cell lines. Toxicol Lett (2010) 192: 221-8. doi:10.1016/j.toxlet.2009.10. 025

26. Bartsch H, Castegnaro M, Rojas M, Camus AM, Alexandrov K, Lang M. Expression of pulmonary cytochrome P4501A1 and carcinogen DNA adduct formation in high risk subjects for tobaccorelated lung cancer. Toxicol Lett
(1992) 64-65:477-83. doi:10.1016/ 0378-4274(92)90222-6

27. Kouri RE, Mckinney CE, Slomiany DJ, Snodgrass DR, Wray NP, Mclemore TL. Positive correlation between high aryl hydrocarbon hydroxylase activity and primary lung cancer as analyzed in cryopreserved lymphocytes. Cancer Res (1982) 42:5030-7.

28. Kiyohara C, Nakanishi Y, Inutsuka S, Takayama K, Hara N, Motohiro A, et al. The relationship between CYP1A1 aryl hydrocarbon hydroxylase activity and lung cancer in a Japanese population. Pharmacogenetics (1998) 8:315-23. doi:10.1097/ 00008571-199808000-00005

29. Friedberg EC. How nucleotide excision repair protects against cancer. Nat Rev Cancer (2001) 1:22-33. doi: $10.1038 / 35094000$

30. Yuan J, Narayanan L, Rockwell S, Glazer PM. Diminished DNA repair and elevated mutagenesis in mammalian cells exposed to hypoxia and low pH. Cancer Res (2000) 60:4372-6.

Conflict of Interest Statement: The authors declare that the research was conducted in the absence of any commercial or financial relationships that could be construed as a potential conflict of interest.

Received: 19 February 2013; accepted: 15 October 2013; published online: 28 October 2013.

Citation: Schults MA, Oligschlaeger $Y$, Godschalk RW, Van Schooten F-J and Chiu RK (2013) Loss of VHL in RCC reduces repair and alters cellular response to benzo[a]pyrene. Front. Oncol. 3:270. doi: 10.3389/fonc.2013.00270

This article was submitted to Cancer Epidemiology and Prevention, a section of the journal Frontiers in Oncology.

Copyright (C) 2013 Schults, Oligschlaeger, Godschalk, Van Schooten and Chiu. This is an open-access article distributed under the terms of the Creative Commons Attribution License (CC BY). The use, distribution or reproduction in other forums is permitted, provided the original author(s) or licensor are credited and that the original publication in this journal is cited, in accordance with accepted academic practice. No use, distribution or reproduction is permitted which does not comply with these terms. 